\title{
Two Novel Glycosyl Cinnamic and Benzoic Acids from Korean Black Raspberry (Rubus coreanus) Wine
}

\author{
Jeong-Yong Cho, Seong Ja Kim, Hyoung Jae Lee, and Jae-Hak Moon
}

Received October 19, 2013; revised January 7, 2014; accepted January 12, 2014; published online August 31, 2014

(C) KoSFoST and Springer 2014

\begin{abstract}
Korean black raspberry (Rubus coreanus) wine was solvent-fractionated with $n$-hexane, ethyl acetate, and $n$-butanol and the $n$-butanol layer was purified by various column chromatographic procedures, including Amberlite XAD-2, Sephadex LH-20, and octadecylsilane resins as well as high performance liquid chromatography. Two novel glycosyl cinnamic and benzoic acids were isolated and their structures were $(E)-8-O-\beta$-D-glucopyranosylcinnamic acid (1) and 3'-[O- $\beta$-D-glucopyranosyl)(1" $\rightarrow 6$ ')- $\alpha$-Dpsicofuranosyl] benzoate (2) based on the spectroscopic data obtained by high resolution fast-atom bombardment mass spectroscopy and nuclear magnetic resonance analyses.
\end{abstract}

Keywords: Korean black raspberry wine, Rubus coreanus, (E)-8-O- $\beta$-D-glucopyranosylcinnamic acid, diglycosyl benzoic acid, glucopyranosyl psicofuranose

\section{Introduction}

Korean black raspberry (KBR, Rubus coreanus Miquel.) is a member of Rosaceae family and has been used in traditional folk remedies for liver protection as well as for treating enuresis, asthma, and spermatorrhea in Korea $(1,2)$. In addition, many studies have reported that the fruit exerts various biological effects including anticancer (3), antimicrobial (4), antioxidant (5-7), hepatitis B virus inhibitory (8), antinociceptive, and anti-inflammatory (9) activities. Moreover, the bioactive components of KBR fruit including anthocyanins $(10,11)$, triterpenoids $(12,13)$, flavonoids $(6,7)$, and tannins $(14,15)$ have been identified.

Jeong-Yong Cho, Seong Ja Kim, Hyoung Jae Lee, Jae-Hak Moon ( $ه$ ) Department of Food Science \& Technology, and Functional Food Research Center, Chonnam National University, Gwangju 500-757, Korea Tel: +82-62-530-2141; Fax: +82-62-530-2149

E-mail: nutrmoon@jnu.ac.kr
KBR fruit has been used in various processed foods in Korea (16). In particular, KBR wine (bokbunja ju), which is made by fermenting the ripened fruit, has a deep red color and sweet taste and is a popular Korean alcoholic beverage (16). KBR wine also exerts biological activities including reducing serum cholesterol (17) as well as antioxidant and anti-inflammatory (18), and anticancer (16) effects. Various metabolites from the constituents of KBR fruit produced during KBR wine preparation may contribute to its biological activities. Understanding the constituents of KBR wine is very important in regards to acquiring basic information on processing, preservation, and the biological function of KBR wine. However, studies on the chemical constituents of KBR wine are limited in comparison to those of KBR fruit. Therefore, the chemical constituents contained in KBR wine were investigated. In our previous study, 10 phenolic and volatile compounds were found from the ethyl acetate (EtOAc) layer of KBR wine $(19,20)$. In addition, changes in total phenolics, total anthocyanin, gallic acid (GA), and 3,4-dihydroxybenzoic acid contents and antioxidative activity during KBR wine manufacturing were investigated (21). In the course of our investigation on chemical constituents from KBR wine, two novel phenolic glycosides were additionally isolated. This study describes the isolation and structural elucidation of the two novel glycosyl cinnamic and benzoic acids from the water-saturated $n$-butanol $(\mathrm{BuOH})$ layer of $\mathrm{KBR}$ wine based on the NMR and high resolution-fast-atom bombardment mass spectroscopy (HR-FAB-MS) analyses.

\section{Materials and Methods}

General experimental procedures NMR spectra were obtained with an unitINOVA 500 spectrometer (Varian, Walnut Creek, CA, USA) using the solvent as the internal 
standard. The isolated compounds were dissolved in $\mathrm{CD}_{3} \mathrm{OD}$. Mass spectral data were obtained using HR-FABMS (JMS-HX100; Jeol, Tokyo, Japan) with a matrix ingredient (3-nitrobenzyl alcohol). Column chromatography was performed with Amberlite XAD-2 (20-60 mesh; Sigma, St. Louis, MO, USA), Sephadex LH-20 (25-100 mesh; GE Healthcare Bio-Sciences AB, Uppsala, Sweden), and octadecylsilane (ODS, 170 mesh; YMC, Kyoto, Japan) resins. HPLC separations were performed on a SPD-M20D system (Shimadzu, Kyoto, Japan) with ODS columns [ODS-80Ts column (4.6 i.d. $\times 250 \mathrm{~mm}, 5 \mu \mathrm{m}$; Tosoh, Kyoto, Japan) and $\mu$ Bondapak (7.8 i.d. $\times 300 \mathrm{~mm}, 10 \mu \mathrm{m}$; Waters, Milford, MA, USA)] and RP-amide $\mathrm{C}_{16}(4.6$ i.d. $\times 250 \mathrm{~mm}$; Supelco, Bellefonte, PA, USA). Detection was accomplished at $280 \mathrm{~nm}$ with a flow rate of either 1.0 or $2.0 \mathrm{~mL} / \mathrm{min}$. TLC was performed on silica gel $60 \mathrm{~F}_{254}(0.25-\mathrm{mm}$ thickness; Merck, Darmstadt, Germany).

Materials and chemicals The fruits of $R$. coreanum were collected in June 2009 from Naju city, Korea. A voucher sample was deposited in the warm-temperate forest arboretum located on Bogil Island, Chonnam National University (Gwangju, Korea).

Preparation of KBR wine The manufacture of the KBR wine was carried out according to the mass-production method (19) of Yeon-Su Dang Manufacturing Co. (Gwangju, Korea). Briefly, KBR wine $(11.7 \mathrm{~L})$ was prepared from ripened KBR fruit $(15.7 \mathrm{~kg})$ without the addition of other ingredients. The alcoholic content of KBR wine was about $13.0 \%$.

Extraction and purification The KBR wine $(11.7 \mathrm{~L}$, $15.7 \mathrm{~kg}$ fresh fruit equivalent) was concentrated in vacuo to remove the ethanol. The concentrated aqueous layer (2.8 L) was successively partitioned with $n$-hexane $(3 \mathrm{~L}, 3$ times), EtOAc (3 L, 3 times), and $\mathrm{BuOH}$ (3 L, 3 times). The BuOH layer $(138.5 \mathrm{~g})$ was fractionated by chromatography on an Amberlite XAD-2 column $(8.0$ i.d. $\times 58 \mathrm{~cm})$ and eluted with $\mathrm{H}_{2} \mathrm{O} / \mathrm{MeOH}=8: 2,6: 4,4: 6,2: 8$, and $0: 10(\mathrm{v} / \mathrm{v}$, each $5.6 \mathrm{~L}$ ). Each column chromatographic fraction was spotted on a silica gel TLC plate and developed using a mixture of $\mathrm{MeOH} /$ acetic acid/water $(7: 1: 2, \mathrm{v} / \mathrm{v} / \mathrm{v})$. The spots were detected by UV light ( 254 and $365 \mathrm{~nm}$ ). Thirtyone fractions (BL1-HL31) were separated by Amberlite XAD-2 column chromatography of the $\mathrm{BuOH}$ layer. Fraction BL8 (4.9 g, $\mathrm{H}_{2} \mathrm{O} / \mathrm{MeOH}=8: 2$, v/v) was chromatographed on a Sephadex LH-20 column $(2.0$ i.d. $\times 132 \mathrm{~cm}$, bed volume $480 \mathrm{~mL}$ ) using $100 \% \mathrm{MeOH}$ as an elution solvent to obtain 5 fractions (BL8.1-BL8.5). BL8.3 (2.17 g) was further fractionated by Sephadex LH-20 $(1.5$ i.d. $\times 80 \mathrm{~cm}$, bed volume $480 \mathrm{~mL}$ ) column chromatography using $10 \%$ $\mathrm{MeOH}$ as an elution solvent to afford 3 fractions (BL8.3a-
BL8.3c). Fraction BL8.3c (464 mg) was further fractionated with an ODS column $(2.3$ i.d. $\times 53 \mathrm{~cm})$ and eluted with $\mathrm{H}_{2} \mathrm{O} / \mathrm{MeOH}$ (90:10, 80:20, 75:25, 70:30, 65:35, 60:40, $55: 45,50: 50, \mathrm{v} / \mathrm{v}$, each $350 \mathrm{~mL}$ ) to give 5 fractions (BL8.3c1-BL8.3c5). Fraction BL8.3c4 $\left(\mathrm{H}_{2} \mathrm{O} / \mathrm{MeOH}=\right.$ $65: 35, \mathrm{v} / \mathrm{v}, 25 \mathrm{mg}$ ) was subjected to HPLC using an ODS$80 \mathrm{Ts}$ column and a gradient system of $20 \% \mathrm{MeOH}$ [pH 2.6, by trifluoroacetic acid (TFA), eluent A] to $80 \% \mathrm{MeOH}$ (eluent B): $100 \%$ A was started, increased to $100 \%$ B over $40 \mathrm{~min}$, and held at $100 \%$ B until $50 \mathrm{~min}$. After repeated purification, compound 1 ( $t_{R} 14.8 \mathrm{~min}, 1.6 \mathrm{mg}$, white amorphous powder) was isolated.

Fraction BL10 (4.9 g, $\mathrm{H}_{2} \mathrm{O} / \mathrm{MeOH}=6: 4$, v/v), obtained after Amberlite XAD-2 column chromatography, was fractionated on a Sephadex LH-20 column $(1.5$ i.d. $\times 80 \mathrm{~cm}$, bed volume $480 \mathrm{~mL}$ ) using $100 \% \mathrm{MeOH}$ as the eluent to obtain 11 fractions (BL10.1-BL10.11). Fraction BL10.4 $(48.9 \mathrm{mg})$ was subjected to HPLC equipped with a $\mu$ Bondapak column with a gradient system of $20 \% \mathrm{MeOH}$ (pH 2.6, TFA) to $100 \% \mathrm{MeOH} ; 100 \%$ A was held for 5 min, increased to $100 \%$ B over $35 \mathrm{~min}$, and held at $100 \%$ B until $50 \mathrm{~min}$. After repeated purification, 11 fractions including BL10.3d were purified. Finally, fraction BL10.3d $(19.0 \mathrm{mg})$ was subjected to HPLC using an RP-amide $\mathrm{C}_{16}$ (4.6 i.d. $\times 250 \mathrm{~mm})$ column and eluting with $5 \% \mathrm{MeOH}(\mathrm{pH}$ 2.6, TFA) as a mobile phase to obtain $2\left(t_{R} 15.3 \mathrm{~min}\right.$, $2.4 \mathrm{mg})$.

\section{Results and Discussion}

After solvent fractionation of the KBR wine (11.7 L, 15.7 $\mathrm{kg}$ fresh fruit equivalent), $n$-hexane $(0.2 \mathrm{~g})$, EtOAc (56.2 $\mathrm{g}$ ), $\mathrm{BuOH}$ (138.5 g), and aqueous (731.5 g) layers were obtained. Of them, the EtOAc layer has been investigated in our previous studies to isolate and identify the chemical constituents in KBR wine $(19,20)$. In the present study, the $\mathrm{BuOH}$ layer was used for a series of investigations on screening of useful compounds from KBR wine. The $\mathrm{BuOH}$ layer $(138.5 \mathrm{~g})$ of the KBR wine $(11.7 \mathrm{~L}, 15.7 \mathrm{~kg}$ fresh fruit equivalent) was fractionated by various column chromatographic procedures, including Amberlite XAD-2, Sephadex LH-20, and ODS as well as HPLC to obtain two novel compounds (1, $1.6 \mathrm{mg} ; \mathbf{2}, 2.4 \mathrm{mg})$. Compounds $\mathbf{1}$ and 2 were structurally elucidated as novel glycosyl cinnamic and benzoic acids based on NMR and MS spectroscopic data.

Compound 1 was isolated as a white amorphous powder. The molecular formula $\left(\mathrm{C}_{15} \mathrm{H}_{18} \mathrm{O}_{8}\right)$ of $\mathbf{1}$ was determined by HR-FAB-MS (positive) spectrum $\left(\mathrm{m} / z 327.1077[\mathrm{M}+\mathrm{H}]^{+}\right.$; calculated for $\mathrm{C}_{15} \mathrm{H}_{19} \mathrm{O}_{8}, \mathrm{~m} / z$ 327.1077, $0 \mathrm{mmu}$ ). The ${ }^{13} \mathrm{C}$ NMR (125 MHz, $\left.\mathrm{CD}_{3} \mathrm{OD}\right)$ spectrum revealed the presence of nine carbon signals assignable to a phenylpropanoid 


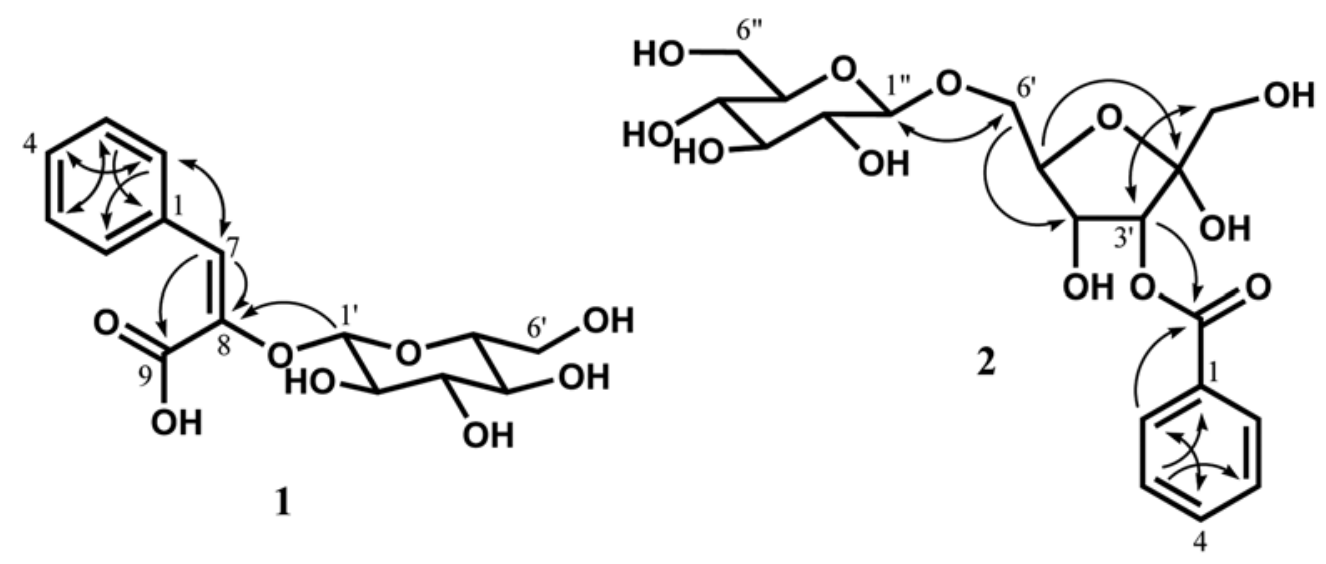

Fig. 1. Structures and HMBC correlations (arrows) of the compounds isolated from KBR wine.

including a carbonyl carbon signal at $\delta 167.3$ (C-9) and eight other carbon signals at $\delta 142.9-126.0$, and in addition to six carbon signals assignable to a sugar moiety at $\delta$ 103.0 (C-1'), 78.2 (C-2'), 75.8 (C-3'), 71.5 (C-4'), 78.8 (C$\left.5^{\prime}\right)$, and $62.7\left(\mathrm{C}-6^{\prime}\right)$. That is, the ${ }^{1} \mathrm{H}-\mathrm{NMR}(500 \mathrm{MHz}$, $\left.\mathrm{CD}_{3} \mathrm{OD}\right)$ spectrum of $\mathbf{1}$ showed the presence of monosubstituted benzene ring proton signals $[\delta 7.86(2 \mathrm{H}, \mathrm{d}$, $J=7.5 \mathrm{~Hz}, \mathrm{H}-2,6), 7.35$ (2H, t, $J=7.5 \mathrm{~Hz}, \mathrm{H}-3,5)$, and 7.30 $(1 \mathrm{H}, \mathrm{d}, J=7.5 \mathrm{~Hz}, \mathrm{H}-4)]$ and a proton signal $[\delta 7.05(1 \mathrm{H}, \mathrm{s}$, $\mathrm{H}-7)$ ] of a double bond, suggesting that aglycone of $\mathbf{1}$ was hydroxylcinnamic acid. Sugar proton signals including an anomeric proton signal $\left[\delta 5.21\left(1 \mathrm{H}, \mathrm{d}, J=8.0 \mathrm{~Hz}, \mathrm{H}-1^{\prime}\right)\right]$ and other proton signals $\left[\delta 3.75-3.23\left(6 \mathrm{H}, \mathrm{H}-2^{\prime} \sim \mathrm{H}-6^{\prime}\right)\right]$ were also found. The configuration of $\beta$-D-glucopyranose was indicated by the proton-proton correlations in the ${ }^{1} \mathrm{H}$ ${ }^{1} \mathrm{H}$ correlation spectroscopy (COSY) spectrum and the coupling constant values $(J=8.0-9.0 \mathrm{~Hz})$ of the sugar protons in the ${ }^{1} \mathrm{H}-\mathrm{NMR}$ spectrum. In addition, all carbons were assigned according to the results of the heteronuclear single quantum correlation (HSQC) analysis. The aglycone moiety was assigned as 8-hydroxycinnamic acid on the basis of ${ }^{1} \mathrm{H}-{ }^{13} \mathrm{C}$ long-range correlations in the heteronuclear multi-bond correlation (HMBC) spectrum (Fig. 1). In addition, the correlation between $\mathrm{H}-1^{\prime}(\delta 5.21)$ and $\mathrm{C}-8(\delta$ 142.9) indicated that glucose was etherified at the C-8 position of 8-hydroxycinnamic acid. Therefore, the structure of 1 was elucidated to be 8-O- $\beta$-D-glucopyranosylcinnamic acid. However, the stereoisomeric structure in the olefinic double bond of the aglycone was not yet clear. Therefore, compound 1 was additionally analyzed by ${ }^{1} \mathrm{H}-\mathrm{NMR}$ with $\mathrm{D}_{2} \mathrm{O}$ to compare with data of a known compound. That is, the chemical shift $(\delta 7.07,1 \mathrm{H}, \mathrm{s}, \mathrm{H}-7)$ of the olefinic double bond proton signal in the ${ }^{1} \mathrm{H}-\mathrm{NMR}$ spectrum (500 $\mathrm{MHz}, \mathrm{D}_{2} \mathrm{O}$, Table 1) of $\mathbf{1}$ was observed down-field at 0.35 ppm when compared to that $(\delta$ 6.72) of $(Z)-8-O-\beta-\mathrm{D}-$ glucopyranosylcinnamic acid previously identified from the leaves of Onobrychis viciifolia (22). Consequently, the structure of 1 was elucidated as $(E)-8-O-\beta$-D-glucopyranosylcinnamic acid (Fig. 1).

Compound 2 was isolated as a white amorphous powder. Its molecular formula $\left(\mathrm{C}_{19} \mathrm{H}_{26} \mathrm{O}_{12}\right)$ was obtained from the HR-FAB-MS $\left(\mathrm{m} / z 469.1327[\mathrm{M}+\mathrm{Na}]^{+}\right.$; calculated for $\mathrm{C}_{19} \mathrm{H}_{26} \mathrm{O}_{12} \mathrm{Na}, \mathrm{m} / z$ 469.1327, $0.0 \mathrm{mmu}$ ) data. The ${ }^{1} \mathrm{H}-$ NMR $\left(500 \mathrm{MHz}, \mathrm{CD}_{3} \mathrm{OD}\right)$ spectrum of 2 revealed the presence of mono-substituted benzene ring proton signals [ $\delta 8.08(2 \mathrm{H}, \delta, J=7.5 \mathrm{~Hz}, \mathrm{H}-2,6), 7.49(2 \mathrm{H}, \mathrm{t}, J=7.5 \mathrm{~Hz}$, $\mathrm{H}-3,5)$, and $7.61(1 \mathrm{H}, \mathrm{t}, J=7.5 \mathrm{~Hz}, \mathrm{H}-4)$ ] (Table 2). This was supported by the ${ }^{13} \mathrm{C}-\mathrm{NMR}\left(125 \mathrm{MHz}, \mathrm{CD}_{3} \mathrm{OD}\right)$ spectrum, which showed the presence of carbon signals assignable to a benzoyl moiety at $\delta 168.0$ (C-7), 134.4 (C4), 131.8 (C-1), 130.0 (C-2, 6), and 129.7 (C-3, 5). In addition, 12 carbon signals of two sugar moieties at $\delta$ 104.8-62.4 were observed. The configuration of $\beta$-Dglucopyranose was assigned by the proton-proton correlations in the ${ }^{1} \mathrm{H}-{ }^{1} \mathrm{H}$ COSY experiments and their coupling constant values $(J=7.5-9.0 \mathrm{~Hz})$ in the ${ }^{1} \mathrm{H}-\mathrm{NMR}$ spectrum. The other sugar was assigned as $\alpha$-D-psicofuranose by the ${ }^{1} \mathrm{H}-\mathrm{NMR},{ }^{1} \mathrm{H}-{ }^{1} \mathrm{H}$ COSY, HSQC, and nuclear Overhauser effect (NOE) experiments. That is, a series of correlations in cross peaks of $\mathrm{H}-3^{\prime} / \mathrm{H}-4^{\prime}, \mathrm{H}-4^{\prime} / \mathrm{H}-5^{\prime}$, and $\mathrm{H}-5^{\prime} / \mathrm{H}-6^{\prime}$ in the ${ }^{1} \mathrm{H}-{ }^{1} \mathrm{H}$ COSY spectrum were found. The coupling constant $(J)$ of H-3' $(\delta 5.31)$ and $\mathrm{H}-4^{\prime}(\delta 4.10)$ was $3.5 \mathrm{~Hz}$. The spatial interactions between $\delta 4.17$ (H-1') and $\delta 5.31\left(\mathrm{H}-3^{\prime}\right), 4.10\left(\mathrm{H}-4^{\prime}\right)$, and $3.96\left(\mathrm{H}-6^{\prime}\right)$ were observed in the NOE experiment (data not shown). In addition, the HMBC spectrum of $\mathbf{2}$ showed correlations between the anomeric proton ( $\delta 4.43, \mathrm{C}-1 ")$ of glucose and the methylene carbon signal $\left(\delta 72.9, \mathrm{C}-6^{\prime}\right)$ of psicose (Fig. $1)$. The disaccharide moiety of $\mathbf{2}$ was assigned as $\alpha-\mathrm{D}-(O-$ $\beta$-D-glucopyranosyl)(1" $\left.\rightarrow 6^{\prime}\right)$-psicofuranose. Moreover, the cross peaks of $\mathrm{H}-3^{\prime}(\delta 5.31)$ and the carbonyl carbon signal $(\delta$ 168.0, C-7) indicated that benzoic acid was esterified with the C-3' position of psicose. Therefore, the structure of 2 was determined to be $3^{\prime}$-[O- $\beta$-D-glucopyranosyl) $\left(1^{\prime \prime} \rightarrow 6^{\prime}\right)$ - 
Table 1. ${ }^{1} \mathrm{H}-(500 \mathrm{MHz})$ and ${ }^{13} \mathrm{C}-(125 \mathrm{MHz})$ NMR data of compound 1

\begin{tabular}{cccc}
\hline Position & $\delta_{\mathrm{C}}{ }^{1)}$ & $\begin{array}{c}\delta_{\mathrm{H}} \\
(\text { rel. int., multi, } J \text { in Hz })^{1)}(\text { rel. int., multi, } J \text { in Hz })^{2)}\end{array}$ \\
\hline 1 & 134.9 & - & - \\
2,6 & 131.8 & $7.86(2 \mathrm{H}, \mathrm{d}, 7.5)$ & $7.78(2 \mathrm{H}, \mathrm{d}, 7.0)$ \\
3,5 & 129.5 & $7.35(2 \mathrm{H}, \mathrm{t}, 7.5)$ & $7.37(2 \mathrm{H}, \mathrm{t}, 7.0)$ \\
4 & 130.2 & $7.30(1 \mathrm{H}, \mathrm{t}, 7.5)$ & $7.35(1 \mathrm{H}, \mathrm{t}, 7.0)$ \\
7 & 126.0 & $7.05(1 \mathrm{H}, \mathrm{s})$ & $7.07(1 \mathrm{H}, \mathrm{s})$ \\
8 & 142.9 & - & - \\
9 & 167.3 & - & - \\
$1^{\prime}$ & 103.0 & $5.21(1 \mathrm{H}, \mathrm{d}, 8.0)$ & $5.00(1 \mathrm{H}, \mathrm{d}, 7.8)$ \\
$2^{\prime}$ & 78.2 & $3.49(1 \mathrm{H}, \mathrm{dd}, 9.0,8.0)$ & $3.49(1 \mathrm{H}, \mathrm{dd}, 9.0,7.8)$ \\
$3^{\prime}$ & 75.8 & $3.41(1 \mathrm{H}, \mathrm{dd}, 9.0,9.0)$ & $3.43(1 \mathrm{H}, \mathrm{dd}, 9.0,9.0)$ \\
$4^{\prime}$ & 71.5 & $3.36(1 \mathrm{H}, \mathrm{dd}, 9.0,9.0)$ & $3.36(1 \mathrm{H}, \mathrm{dd}, 9.0,9.0)$ \\
$5^{\prime}$ & 78.8 & $3.23(1 \mathrm{H}, \mathrm{ddd}, 12.0,5.5,2.5)$ & $3.28(1 \mathrm{H}, \mathrm{m})$ \\
$6^{\prime} \mathrm{a}$ & 62.7 & $3.75(1 \mathrm{H}, \mathrm{dd}, 12.0,2.5)$ & $3.69(1 \mathrm{H}, \mathrm{dd}, 12.0,2.5)$ \\
$6^{\prime} \mathrm{b}$ & & $3.61(1 \mathrm{H}, \mathrm{dd}, 12.0,5.5)$ & $3.56(1 \mathrm{H}, \mathrm{dd}, 12.0,5.5)$ \\
\hline
\end{tabular}

${ }^{1) 1} \mathrm{H}$ - and ${ }^{13} \mathrm{C}$-NMR spectra were determined in $\mathrm{CD}_{3} \mathrm{OD}$.

${ }^{2) 1} \mathrm{H}-\mathrm{NMR}$ spectrum was determined in $\mathrm{D}_{2} \mathrm{O}$.

Table 2. ${ }^{1} \mathrm{H}-(500 \mathrm{MHz})$ and ${ }^{13} \mathrm{C}-(125 \mathrm{MHz})$ NMR data of compound 2 in $\mathrm{CD}_{3} \mathrm{OD}$

\begin{tabular}{ccc}
\hline Position & $\delta_{\mathrm{H}}($ rel. int., multi, $J$ in $\mathrm{Hz})$ & $\delta_{\mathrm{C}}$ \\
\hline 1 & - & 131.8 \\
2,6 & $8.08(2 \mathrm{H}, \mathrm{d}, 7.5)$ & 130.0 \\
3,5 & $7.49(2 \mathrm{H}, \mathrm{t}, 7.5)$ & 129.7 \\
4 & $7.61(1 \mathrm{H}, \mathrm{t}, 7.5)$ & 134.4 \\
7 & - & 168.0 \\
$1^{\prime} \mathrm{a}$ & $4.17(1 \mathrm{H}, \mathrm{d}, 12.8)$ & 62.4 \\
$1^{\prime} \mathrm{b}$ & $3.79(1 \mathrm{H}, \mathrm{d}, 12.8)$ & 99.2 \\
$2^{\prime}$ & - & 74.7 \\
$3^{\prime}$ & $5.31(1 \mathrm{H}, \mathrm{d}, 3.5)$ & 70.0 \\
4' & $4.10(1 \mathrm{H}, \mathrm{dd}, 10.0,3.5)$ & 70.8 \\
5' & $3.94(1 \mathrm{H}, \mathrm{d}, 10.0)$ & 72.9 \\
6'a & $3.96(1 \mathrm{H}, \mathrm{br} . \mathrm{d} ., 12.5)$ & 104.8 \\
6'b & $3.84(1 \mathrm{H}, \mathrm{br} . \mathrm{d}, 12.5)$ & 75.3 \\
$1^{\prime \prime}$ & $4.43(1 \mathrm{H}, \mathrm{d}, 7.5)$ & 78.1 \\
$2^{\prime \prime}$ & $3.26(1 \mathrm{H}, \mathrm{dd}, 9.0,7.5)$ & 71.6 \\
3" & $3.37(1 \mathrm{H}, \mathrm{dd}, 9.0,7.5)$ & 78.2 \\
4" & $3.31(1 \mathrm{H})^{1)}$ & 62.8 \\
5" & $3.28(1 \mathrm{H}, \mathrm{m})$ & \\
6"a & $3.86(1 \mathrm{H}, \mathrm{dd}, 12.0,1.2)$ & \\
6"b & $3.65(1 \mathrm{H}, \mathrm{dd}, 12.0,5.0)$ &
\end{tabular}

${ }^{1)}$ Chemical shifts of H-4" and solvent overlapped.

$\alpha$-D-psicofuranosyl] benzoate (Fig. 1).

We isolated two novel glycosyl cinnamic and benzoic acids from the $\mathrm{BuOH}$ layer of $\mathrm{KBR}$ wine. These novel compounds were structurally elucidated as $(E)-8-O-\beta-\mathrm{D}-$ glucopyranosylcinnamic acid (1) and $3^{\prime}-[O-\beta-\mathrm{D}-$ glucopyranosyl)(1" $\left.\rightarrow 6^{\prime}\right)-\alpha$-D-psicofuranosyl] benzoate (2) (Fig. 1). These compounds have not been identified in nature. However, (Z)-8-O- $\beta$-D-glucopyranosylcinnamic acid, which is an isomer of $\mathbf{1}$, has been previously identified from the leaves of $O$. viciifolia. Therefore, compound $\mathbf{1}$ might have been produced during wine manufacturing or occurred during isolation of the $Z$ form. In addition, glucopyranosylpsicofuranose contained as a partial structure in $\mathbf{2}$ is produced by glucosyltransferase from microorganisms (23). Therefore, compound $\mathbf{2}$ might be produced by the action of microorganisms during wine manufacturing. However, we do not know whether the two novel glycosyl cinnamic and benzoic acids originated in KBR wine or its fresh fruit. Therefore, the occurrence of the two novel glycosyl cinnamic and benzoic acids in KBR wine or its fresh fruit as well as their biological effects should be further studied.

Disclosure The authors declare no conflict of interest.

\section{References}

1. Eu GS, Chung BY, Bandopadhyay R, Yoo NH, Choi DC, Yun SY. Phylogenic relationships of Rubus species revealed by randomly amplified polymorphic DNA markers. J. Crop Sci. Biotech. 11: 3944 (2008)

2. Park JH, Lee HS, Mun HC, Kim DH, Seong NS, Jung HG, Bang JK, Lee HY. Effect of ultrasonification process on enhancement of immuno-stimulatory activity of Ephedera sinica Stapf and Rubus coreanus Miq. Korean J. Biotechnol. Bioeng. 19: 113-117 (2004)

3. Lee MK, Lee HS, Choi GP, Oh DH, Kim JD, Yu CY, Lee HY. Screening of biological activities of the extracts from Rubus coreanus Miq. Korean J. Med. Crop Sci. 11: 5-12 (2003)

4. Cha HS, Park MS, Park KM. Physiological activities of Rubus coreanus Miquel. Korean J. Food Sci. Technol. 33: 409-415 (2001)

5. Yoon I, Cho JY, Kook JH, Wee JH, Jang MY, Ahn TH, Park KH. Identification and activity of antioxidative compounds from Rubus coreanum fruit. Korean J. Food Sci. Technol. 34: 898-904 (2002)

6. Yoon I, Wee JH, Ahn TH, Park KH. Isolation and identification of quercetin with antioxidative activity from the fruits of Rubus coreanum Miquel. Korean J. Food Sci. Technol. 35: 499-502 (2003)

7. Cho JY, Yoon I, Jung DH, Hyun SH, Lee KH, Moon JH, Park KH. Jaboticabin and flavonoids from the ripened fruit of black raspberry (Rubus coreanum). Food Sci. Biotechnonol. 21: 1081-1086 (2012)

8. Chung TH, Kim JC, Lee CY, Moon MK, Chae SC, Lee IS, Kim SH, Hahn KS, Lee IP. Potential antiviral effects of Terminalia chebula, Sanguisorba officinalis, Rubus coreanus, and Rheum palmatum against duck hepatitis B virus (DHBV). Phytother. Res. 11: 179-182 (1997)

9. Choi JW, Lee KT, Ha JH, Yun SY, Ko CD, Jung HJ, Park HJ. Antinociceptive and anti-inflammatory effects of niga-ichigoside F1 and 23-hydroxytormentic acid obtained from Rubus coreanus. Biol. Pharm. Bull. 26: 1436-1441 (2003)

10. Hong V, Wrolstad RE. Use of HPLC separation/photodiode array detection for characterization of anthocyanins. J. Agr. Food Chem. 38: $708-715$ (1990)

11. Tulio AZ Jr, Reese RN, Wyzgoski FJ, Rinaldi RL, Fu R, Scheerens JC, Miller AR. Cyanidin 3-rutinoside and cyanidin 3-xylosylrutinoside as primary phenolic antioxidant in black raspberry. J. Agr. Food Chem. 56: 1880-1888 (2008)

12. Ohtani K, Miyajima C, Takahasi T, Kasai R, Tanaka O, Hahn DR, Naruhashi N. A dimeric triterpene-glycoside from Rubus coreanus. Phytochemistry 29: 3275-3280 (1990)

13. Kim YH, Kang SS. Triterpenoids from Rubi fructus (bogbunja). Arch. Pharm. Res. 16: 109-113 (1993)

14. Lee YA, Lee MW. Tannins from Rubus coreanum. Korean J. 
Pharmacogn. 26: 27-30 (1995)

15. Pang GC, Kim MS, Lee MW. Hydrolyzable tannins from the fruits of Rubus coreanum. Korean J. Pharmacogn. 27: 366-370 (1996)

16. Jung JW, Son MY, Jung SW, Nam PW, Sung JS, Lee SJ, Lee KG. Antioxidant properties of Korean black raspberry wines and their apoptotic effects on cancer cell. J. Sci. Food Agr. 89: 970-977 (2009)

17. Kwon KH, Cha WS, Kim DC, Shin HJ. A research and application of active ingredients in Bokbunja (Rubus coreanus Miquel.). Korean J. Biotechnol. Bioeng. 21: 405-409 (2006)

18. Jeong JH, Jung H, Lee SR, Lee HJ, Hwang KT, Kim TY. Antioxidant, anti-proliferative, and anti-inflammatory activities of the extracts from black raspberry fruits and wine. Food Chem. 123: 338-344 (2010)

19. Kim SJ, Lee HJ, Park KH, Rhee CO, Lim IJ, Chung HJ, Moon JH. Isolation and identification of low molecular phenolic antioxidants from ethylacetate layer of Korean black raspberry (Rubus coreanus) wine. Korean J. Food Sci. Technol. 40: 129-134 (2008)

20. Cho JY, Kim SJ, Lee HJ, Kim JY, Lym IJ, Kang SK, Park KH, Moon JH. Isolation and identification of low molecular volatile compounds form ethyl acetate layer of Korean black raspberry (Rubus coreanus Miq.) wine. Korean J. Food Sci. Technol. 43: 558563 (2011)

21. Cho JY, Jeong JH, Kim JY, Kim SR, Kim SJ, Lee HJ, Lee SH, Park $\mathrm{KH}$, Moon JH. Change in the content of phenolic compounds and antioxidant activity during manufacturing of black raspberry (Rubus coreanus Miq.) wine. Food Sci. Biotechnonol. 22: 1237-1244 (2013)

22. Lu YR, Sun Y, Foo Y, Manabb WC, Molan AL. Phenolic glycosides of forage legume Onobrychis viciifolia. Phytochemistry 55: 67-75 (2000)

23. Oshima H, Kimura I, Morimoto K, Izumori K. Synthesis and structure analysis of glucosylpsicose produced by cyclomaltodextrin glucanotransferase. J. Appl. Glycosci. 55: 1-3 (2008) 